\title{
USAGE OF RENEWABLE ENERGY IN RURAL AREAS
}

\author{
P. Rathna \\ Research Scholar \\ Department of Management Studies \\ Bharath Institute of Higher Education and Research, \\ Chennai-600073, Tamil Nadu, India
}

\begin{abstract}
This paper investigations the present status of rustic sustainable power source (RRE) in China and India, creates and utilizes an examination structure to think about the earth, channels, instruments and inventive components of financing provincial sustainable power source in China and India, and makes an essential correlation.
\end{abstract}

Keywords - Environment, Households, Power, Population, Rural Areas

\section{INTRODUCTION}

Vitality is centre part in creating economy, killing destitution and enhancing expectations for everyday comforts. It contributes specifically to meeting both essential needs and progressively advanced human needs. Be that as it may, numerous family units, independent companies, and networks in provincial regions of both China and India have no entrance to electric frameworks or present day cooking fills. More than 800 million of China's complete populace of 1.3 billion occupants live in provincial regions, of which 30 million individuals still don't approach power. India represents $33 \%$ of the total populace without access to power and about $40 \%$ of those without access to current vitality. Of the 87 million rustic family units, not over 30\% approach power. By and by, a large portion of the supposed energized towns don't have dependable, normal, sufficient, or great quality power. Residents depend on lamp fuel for lighting and biomass powers (regularly consumed in wasteful stoves, for example, wood, creature excrement and agrarian build-ups for cooking. Absence of vitality is among the key impeding powers anticipating monetary improvement and thusly backing off neediness lightening and development of the rustic part. To meet its financial, social, political and provincial advancement objectives based framework expansion are using inclusion, and must keep on being a noteworthy piece of the vitality get to condition in two nations, China India still face some significant issues. These are:

(a) Shortage of petroleum products. The two nations officially rank among the world's best fifth vitality buyers with amazing monetary development rates nearing $10 \%$ every year. China's

\author{
Dr. A. Ravikumar \\ Research Supervisor \& Associate Professor \\ Department of Management Studies \\ Bharath Institute of Higher Education and Research, \\ Chennai-600073, Tamil Nadu, India
}

development rate of the utilization of vitality has expanded 4.3\% every year since 1980 and India's has been $5.4 \%$. In 2006, China's complete vitality utilization was 2.46 billion tons of standard coal comparable. India devours about $4 \%$ of the world's all out vitality every year. The International Energy Agency in Paris estimates that $66 \%$ of all future vitality requests will exude from simply the two nations. China and India have rich coal assets (China is the main coal maker, and India has the fourth biggest coal holds on the planet), however a large portion of the coal is chiefly singed specifically with low effectiveness. The two countries have along these lines oil and gas assumes a relatively vital job in their national monetary and social advancement. China's oil request has been developing at a normal 7\% since 1990, and keeping in mind that it's presently the world's second biggest purchaser of oil after the United States. Oil includes $36 \%$ of Indian essential vitality utilization in 2005 , and is required to develop from 119 million tons oil proportionate (MTOE), from 2004, to 250 MTOE, amid 2025, at a yearly development of $3.6 \%$. Be that as it may, their household oil can't address the issue of monetary and social advancement. China imports half of its oil utilization and India imports over 70\%. In spite of the fact that the two countries are two Asian mammoths that expend just a third as much oil as the US today, by 2030 China and India together will import as much oil as the US and Japan do today.

(b) Environmental obliges. As their utilization of petroleum products quickens, so will India's and China's discharges of ozone harming substances, for example, carbon dioxide. Albeit today they contribute just $4 \%$ and $14 \%$, individually, to add up to worldwide carbon dioxide outflows, emanating only $10 \%$ as much ozone harming substance per capital as North America, India's and China's discharges are ascending far quicker. These figures are anticipated to increment to $5 \%$ and $18 \%$ by 2025 . This speaks to a $3.3 \%$ yearly normal rate increment by China throughout the following 20 years, and a $2.9 \%$ expansion for India.

(c) Higher expense. The matrix expansion is regularly more costly in rustic zones than in urban regions in light of its lower load densities, low limit usage rates, high power line misfortunes, and prerequisite for going with framework 


\section{International Journal of Engineering Applied Sciences and Technology, 2019 \\ Vol. 4, Issue 5, ISSN No. 2455-2143, Pages 168-174 \\ Published Online September 2019 in IJEAST (http://www.ijeast.com)}

improvement, for example, street building. Stretching out the lines to rustic regions in this manner would just expand the expenses of the general produced power. Stretching out the electric lattice to remote and low-thickness provincial zones can cost multiple times more than giving power in a urban region. Clearly with such constrained vitality assets, it is hard to satisfy the vitality needs of urban zones and enterprises, not to mention taking care of vitality issue in rustic territory with non-renewable energy source. Indeed, the brought together utility model isn't generally the best channel to convey new vitality administrations to those at present without access. With the appearance of develop sustainable power source advances, the supply of capacity to remote provincial regions from the brought together framework is ending up less focused, just as being progressively destructive to nature and requiring increasingly broad foundation.

(d) Numerous examinations demonstrate that the improvement of provincial sustainable power source relies upon an assortment of socio-techno-monetary institutional elements, yet the financing is a key fixing. Be that as it may, up to now some primary issues of the financing for rustic sustainable power source in China and India have not been enough investigated as well as looked for after. In this manner, it is important to direct research identified with the financing provincial sustainable power source in China and India. In this examination an investigation structure for financing country sustainable power source is produced. In this investigation structure:

(1) Many confused issues of financing rustic sustainable power source in China and India are delegated four sorts, including nature, channels, instruments and imaginative components of financing country sustainable power source.

(2) Financing condition is characterized as administrative, authoritative and strategy conditions.

(3) Financing channel is characterized as the wellspring of financing.

(4) Financing instrument is characterized as the particular conveying strategy for financing.

The rest of the segments of paper are displayed as pursues:

Segment 2 investigations the present status of provincial sustainable power source in India and China.

Area 3 creates and utilizes an investigation structure to consider the earth, channels, instruments and imaginative components of financing rustic sustainable power source in India and China.
Area 4 makes an essential examination of financing country sustainable power source in China and India. Last area comments ends.

\section{$\underline{\text { Table } 1}$}

Primary countries in rural sustainable power condition 2005 [27]

\begin{tabular}{|c|c|c|c|c|c|}
\hline & 1 & 2 & 3 & 4 & 5 \\
\hline $\begin{array}{l}\text { Village } \\
\text { power } \\
\text { small } \\
\text { hydro, } \\
\text { wind, PV, } \\
\text { biomass }\end{array}$ & China & India & Nepal & Vietnam & $\begin{array}{c}\text { Sri } \\
\text { Lanka }\end{array}$ \\
\hline $\begin{array}{c}\text { Water } \\
\text { pumping } \\
\text { mechanical } \\
\text { wind, PV }\end{array}$ & Argentina & China & $\begin{array}{c}\text { South } \\
\text { Africa }\end{array}$ & Namibia & India \\
\hline $\begin{array}{c}\text { Solar home } \\
\text { systems }\end{array}$ & India & China & Thailand & Kenya & $\begin{array}{c}\text { Sri } \\
\text { Lanka }\end{array}$ \\
\hline Biogas & China & India & Nepal & & \\
\hline $\begin{array}{c}\text { Biomass } \\
\text { gasification }\end{array}$ & India & China & & & \\
\hline
\end{tabular}

Source: REN21: Global Status Reports.

\section{The Present Status of Country Sustainable POWER SOURCE IN CHINA AND INDIA}

Both China and India perceive the significance of extending access to current vitality administrations for rustic regions of their nations through the improvement for sustainable power source. They as of now are two world's driving nations in rustic sustainable power source frameworks. China has a noteworthy history of utilization of sustainable power source for rustic advancement, with a portion of the world's provincial biggest projects on little hydro, biomass, wind, PV and biogas. Toward the finish of 2006, the introduced limit with respect to little hydro in China has been 50,000 MW. China has more than 200,000 independent breeze turbines, situated in country regions, with all out introduced limit of 30 MW. At present, there are more than 20 household breeze turbine generator producers in China.

By end of 2005, China's introduced limit of PV frameworks in more than $70 \mathrm{MW}$, of which about half is utilized to supply power to the inhabitants of remote country regions, a market that is developing at $20 \%$ every year. The all out national introduced frameworks so far have surpassed 30 million square meters in development regions. As per the halfway insights, the absolute geothermal siphon deals have surpassed 100 million yuan and are expanding 20\% every year. Toward the finish of 2006, the introduced limit with regards to little hydro in China has been 50,000 MW, with yearly power age more than $150 \mathrm{TW}$ h, which represent $39 \%$ and $36 \%$ of the absolute introduced hydropower limit and yearly hydroelectric age of China, separately. As of late, around 2 million family biogas digesters have been recently manufactured each year. Before the finish of 2005, 18 million family units have embraced biogas innovations, every year 


\section{International Journal of Engineering Applied Sciences and Technology, 2019 \\ Vol. 4, Issue 5, ISSN No. 2455-2143, Pages 168-174 \\ Published Online September 2019 in IJEAST (http://www.ijeast.com)}

delivering biogas 7 billionm 3 and there are 3556 biogas plants, treating creature squanders 87 million tons.

In India, more than 3000 remote and difficult to reach towns and villages have been given essential power benefits through circulated sustainable power frameworks. India is the biggest maker of world's rustic sunlight based home frameworks and biomass Gasification. India's introduced limit with regards to little hydro has been $1850 \mathrm{MW}$ up to 30 September 2006. Provincial utilizations of sun based PV had expanded to 340,000 home lighting frameworks, 540,000 sun oriented lamps, and 7000 sun based power water siphons. There were 600,000 sunlight based cookers being used. India likewise has accomplished 70MW of little scale biomass gasification frameworks for country (off-lattice) control age. Presently, biomass meets $70 \%$ of the fundamental vitality needs of the rustic regions nearly covering $70 \%$ of the populace in India. Around 100,000 biogas plants and 16,530 sunlight based photovoltaic lighting frameworks were introduced amid 2004- 2005.

\section{The FinANCING FOR COUNTRY SuSt AINABLE POWER SOURCE IN CHINA AND INDIA}

Both China and India have for quite some time been perceived the potential for sustainable power source innovations (RETs) as condition well disposed, flexible and reasonable vitality options for provincial zones and have gained incredible ground in sustainable power source in rustic jolt, however RETs have not yet prevailing as a noteworthy elective wellspring of vitality in country regions of the two nations. Moreover, numerous families, independent companies, and networks in country zones of both China and India still have no entrance to electric frameworks or present day cooking powers. In this way, there is requirement for accelerating the advancement for rustic sustainable power source in order to exhaust vitality inclusion to provincial territories. China intends to jolt 10,000 towns and 3.5 million rustic family units with renewable by 2010 . India has as of late proposed to expand cooking, lighting, and intention control with renewable in 600,000 towns by 2032 , beginning with 10,000 remote unjolted towns by 2012 .

The Indian Government has relegated the Ministry for Nonregular Energy Sources to charge 25,000 rustic Indian towns dependent on sustainable power source as a component of the major country jolt program. Be that as it may, up to now some principle issues of the financing for country sustainable power source in China and India have not been sufficiently investigated and additionally looked for after. In this investigation an examination structure for financing country sustainable power source is created. In this investigation structure:

(a) Many convoluted issues of financing rustic sustainable power source in China and India are named four sorts, including the earth, channels, instruments and imaginative components of financing provincial sustainable power source. (b) Financing condition is characterized as administrative, authoritative and approach conditions.

(c) Financing channel is characterized as the wellspring of financing.

(d) Financing instrument is characterized as explicit conveying strategy for financing.

The accompanying segment of this paper utilizes this structure to systematize the issues of the earth, channels, instruments and imaginative components of financing country sustainable power source in China and India.

\section{FinANCING CONDition For Country Sustainable POWER SOURCE}

The great administrative, authoritative and approach conditions are basic for financing provincial sustainable power source. These conditions emphatically influence the conceivable outcomes and aggressiveness of RE, now and then in a way that monetarily suitable country sustainable power source ventures are fiscally not reasonable.

\section{a. China's financing condition:}

China's administration began to focus on sustainable power source improvement in country territories and understood the significance of giving the required administrative, authoritative and strategy support for the financing for rustic sustainable power source in 1970s.

(1) In 1973 the Chinese government proclaimed the Agricultural Law. In the arrangement 57 it unmistakably expresses that agrarian and rustic economy advancement must use and secure common assets, for example, land, water, timberland, meadow and natural life reasonably, sustainable power source and clean vitality, for example, pressure driven vitality, biogas, sun oriented vitality and wind vitality ought to be used and created economically. It is urged to create biological agribusiness and to ensure and enhance natural condition.

(2) In 1996 the Ministry of Electric Power (MOEP) issued the "Parallel Operation Regulations for Wind Power Generation". It necessitates that the power networks must permit interconnection and parallel activities of wind ranches, and that the power lattices must purchase all the power created by the breeze ranches. It further indicates that the price tag should incorporate generation cost, reimbursement of obligation and interests, charges, and a sensible benefit. The distinction in costs between the breeze vitality and the normal market cost ought to be borne by every one of the clients of the power lattice, not simply the clients nearest to the sustainable power source ventures.

(3) The 1998 Energy Conservation Act again perceives and underlines the significance and key job of utilizing sustainable power source to lessen outflows and to ensure the earth.

(4) In 1999, State Planning Commission, through the State Council, endorsed directions to help the advancement of 


\section{International Journal of Engineering Applied Sciences and Technology, 2019 \\ Vol. 4, Issue 5, ISSN No. 2455-2143, Pages 168-174 \\ Published Online September 2019 in IJEAST (http://www.ijeast.com)}

sustainable power source and to quicken the nearby creation of the power gear.

(5) The centre term and long haul improvement approaches have all stressed that country electric advancement will be a basic assignment of China's vitality improvement, the advancement methodologies ought to adjust to nearby conditions, and the significance of little hydro, wind, sun based vitality, geothermal, and biomass assets. Long haul improvement arrangements are chiefly reflected in "China Agenda 21" and "Long Term Objectives on Economic and Social Development of China", particularly "Outline for Development of the New and Renewable Energy in China (1996- 2010)". The sixth, seventh, eighth, ninth, tenth and eleventh "Five-Year Plans" recorded centre term strategies of sustainable power source advancement in China amid the diverse periods.

(6) Strategic anticipating sustainable power source improvement in 2020 Part route through 2003, the National Development and Reform Commission (NDRC) started the detailing of Strategic making arrangements for sustainable power source advancement in 2020, to advance sustainable power source innovation improvement in China and stay aware of world patterns. The methodology depends on sustainable power source assets and innovation attributes in China to meet the social and financial improvement prerequisite, and it draws on remote experience and exercises learned. The technique shows the destinations, format and strategy measures for sustainable power source advancement in China in the following 20 years, managing the way of improvement and development of key activities in the sustainable power source field.

(7) Renewable vitality law, which happened in January 2006, characterizes sustainable power source to incorporate hydroelectricity, wind control, sun based vitality, biomass vitality, geothermal vitality and marine vitality. The law expects to help China's sustainable power source ability to $15 \%$ constantly 2020 and diagrams a promise to put $\$ 180$ billion in sustainable power source over this period. It sets the phase for the across the board improvement of sustainable power source in China, especially for business scale power age offices. It stipulates that the advancement and utilization of sustainable sources are a zone of need for future vitality improvement and requires framework administrators to buy assets from sustainable power source makers, and offers money related motivating forces to encourage sustainable power source improvement, including limited loaning and a scope of tax cuts. Through this enactment, the state authoritatively energizes the development of sustainable power source control offices. China's power matrix is committed to buy all the power produced by affirmed sustainable power source offices situated in its administration region. The network's purchasing cost for sustainable power source is set by the National Development and Reform Commission (NDRC), an administrative branch of the State Council.
(8) The Ministry of Finance in China proclaimed "Interim measures for the organization of exceptional assets for the advancement of sustainable power source" which took impacts on 30th May 2006. The new entomb measures for the organization of exceptional store for the advancement of sustainable power source characterize the extension and standards of the arrangement just as spotlight on explicit advances the legislature is taking to back sustainable power source improvement. This will be helpful for expanding government interest in sustainable power source, better presenting social venture and bank assets into the area, and advancing the advancement of sustainable power source. It is in absolutely this circumstance that the Chinese government has characterized the objectives of this unique reserve and monetary administration approach: logical and innovative work; utilization of sustainable power source assets in remote rural and domesticated animal's zones; investigation of assets; gear assembling and then some. Bolster will be given to key tasks including the improvement of choices to oil, for example, sun powered vitality, geothermal vitality, wind vitality and sea vitality.

\section{a. India's financing condition:}

The significance of the expanding need to give sustainable power sources was perceived by India's administration in the mid 1970s. For almost 40 years, Indian noteworthy endeavours have gone into wind control venture". In India the financed undertakings by global subsidizing essentially include: "Optimizing advancement of little hydel assets in sloping territories", "Indian half and half vitality venture world sustainable otherworldly trust", "India inexhaustible assets improvement venture", "Second sustainable power source venture", "India sustainable power source improvement venture" and "The Commercializing Renewable Energy in India".

\section{b. Business banks and non-bank financing establishments: Inward financing in both China and India will be a huge wellspring of financing. The two nations both have a very much created country keeping money foundation, however the connections to the sustainable power source area are feeble, best case scenario. In the two nations conventional keeping money frameworks are as yet not dynamic in financing rustic sustainable power source in perspective of the high hazard and low benefit related with these credits. Money related foundations are not constantly keen on giving or opening credit extensions for rustic sustainable power source.}

\section{c. Open securities exchanges}

In China and India open securities exchanges have opened to sustainable power source. In India numerous Indian RE organizations have opened up to the world on Indian stock trades. In China the $23 \mathrm{RE}$ undertakings have been recorded on the Shanghai and Shenzhen Stock Exchanges. 


\section{International Journal of Engineering Applied Sciences and Technology, 2019 \\ Vol. 4, Issue 5, ISSN No. 2455-2143, Pages 168-174 \\ Published Online September 2019 in IJEAST (http://www.ijeast.com)}

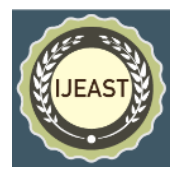

\section{d. Private segment account}

China's private segment account for country sustainable power source, particularly for rustic little hydropower (SHP) has developed quick. For instance, amid 1994- 2002 private interest in new SHP in Zhejiang Province added up to US\$1 billion, representing over $70 \%$ of the aggregate. In 1999 the Indian focal government declared a strategy of opening power age to private support. To enable the private part to make advertise for sustainable power source, IREDA took various measures to bring issues to light among speculators and managing an account of establishments of the feasibility of sustainable power source advances and conquer the obstructions of access to showcase for renewable.

\section{FINANCING INSTRUMENTS FOR COUNTRY SUSTAINABLE POWER SOURCE}

In both China and India various financing instruments have been utilized to encourage financing of country sustainable power source. A diagram of the current financing instruments to help advance interests in the improvement for provincial sustainable power source of the two nations is introduced beneath:

\section{a. Gifts}

Declining money gives on a sliding scale over the life of the venture are incorporated with later undertakings to "push" the market right off the bat and after that enable a progress to a completely business showcase. A few tasks are offered settled money gifts for every framework introduced once accreditation of the establishment is accessible. For instance, in the China Renewable Energy Development extends, a \$100 money allow is paid straightforwardly the SHS merchant.

\section{b. Sustainable power source administration organizations (RESCOs)}

The RESCO idea is most reasonable for little scale sustainable power source frameworks like PV sun based home frameworks (SHS). Instead of offer SHS to mortgage holders, the RESCO move the administration that is delivered by the SHS and thusly gather a month to month charge. The RESCO can total countless into a solitary undertaking as opposed to for each SHS. The purchaser defeats the mind-boggling expense boundary by having just to make little regularly scheduled instalments. Many RESCOs have been set up to give the administrations of offer and establishment and support of family sun oriented PV frameworks in China and India, and sunlight based water warming in India.

\section{c. Low-intrigue and long haul advances}

Indian IREDA gives low-intrigue credits to wind ranch engineers. Credits are relied upon to dynamically approach business showcase rates as the advancements increases more extensive acknowledgment and are viewed as increasingly straightforward and viable at decreasing item costs than direct sponsorships. The India Hilly Hydel venture builds up a spinning reserve, additionally administrated by IREDA, to give low-enthusiasm financing to private business people for little hydel ventures. Like in the India Alternate Energy venture, these credits are required to dynamically approach business showcase rates as the innovation increases more extensive acknowledgment. The India Hilly Hydel venture likewise makes a national system and ground breaking strategy with point by point speculation proposition for extra little hydel ventures. Chinese government has built up explicit low-intrigue advances for country vitality improvement since 1987. Financing cost of exceptional low intrigue credit for extensive and medium biogas ventures, sun oriented vitality applications, and wind advances is just $50 \%$ of that from a perfect business advances. What's more, China additionally builds up exceptional low-intrigue advance projects for little hydro ventures.

\section{d. Resource financing}

China is the third biggest area for resource financing for wind ventures, after US and Spain. In India resource financing was cantered around wind, in spite of the fact that most of venture is by hostage control generators.

\section{e. Funding/private value}

In China Venture capital financing for sustainable power source is taking off. Funding interest in RETs came to $\$ 403$ million of every 2006. Thirteen of the 17 bargains in RETs were in sun oriented, totalling \$367.8 million. Wind control represented two arrangements totalling \$22 million while there were two arrangements in biomass adding up to $\$ 13.2$ million. After the US, China was the second biggest beneficiary of Venture Capital [35]. In 2006, generally 50\% of the VC/PE all out (\$100 million)

\section{f. Sponsorships}

In China the principle endowments for rustic sustainable power source are given by the focal government and the nearby governments more often than not to help research, improvement and exhibit ventures for provincial sustainable power source. In India the appropriations, for example, intrigue endowment and capital sponsorship are mostly given by the Ministry of New and Renewable Energy Sources.

\section{INVENTIVE FINANCING INSTRUMENTS FOR PROVINCIAL SustainABLE POWER SOURCE}

The key issue of financing country sustainable power source in China and India is the accessibility of cash-flow to sustainable power source designers and provincial end-clients, while issues include the expense of cash, the simplicity of getting ease reserves, and institutional complexities that frustrate financing and market development. While traditional subsidizing and monetary instruments, for example, capital 


\section{International Journal of Engineering Applied Sciences and Technology, 2019 \\ Vol. 4, Issue 5, ISSN No. 2455-2143, Pages 168-174 \\ Published Online September 2019 in IJEAST (http://www.ijeast.com)}

endowments, contributor gives, and expense discounts and comparable monetary motivations have possessed the capacity to accomplish a specific dimension of entrance, the expansive scale use and commercialization of sustainable power source items and advances requires inventive ways to deal with the determination and conveyance of money related instruments and channels. Numerous creative systems for financing sustainable power source have been concocted and tried by China and India to advance rustic sustainable power source. These creative financing components incorporate the instruments that consolidate government and network financing (India); advancement of a market-arranged institutional and budgetary model for decentralized heavenly bodies (India); wind-control improvement through blend of the Clean Development Mechanism (CDM) and open division financing (India); scaling-up of inexhaustible town control through legislative account and offering dependent on market direction (China); experience of the first CDM venture in sustainable power source financing in (China); financing the use of landfill gas through monetary motivations (China); commercialisation of sun oriented heated water frameworks through a 'money related middle person (FI) plot' (India); advertise improvement for sun oriented lamps in a postappropriation routine (India) and building up a manageable budgetary model for sunlight based siphoning frameworks (India).

An essential correlation of financing rustic sustainable power source in China and India

(1) Both China and India understand the significance of giving the required administrative, authoritative and approach support for financing country sustainable power source. China has peaked a positive domain for financing provincial sustainable power source. It is one of 48 nations worldwide that have instituted laws for sustainable power source improvement. There is no a National Renewable Energy enactment in India yet. Indeed, even India does not have any Energy Policy today. Be that as it may, an Expert Committee comprised by the Planning Commission has arranged an Integrated Energy Policy Report (IEPR) covering all wellsprings of vitality including sustainable power sources. This report has featured the need to maximally create residential supply alternatives and broaden vitality sources. It has likewise anticipated that renewable may represent 5-6\% of India's vitality blend by $2031-2032$ and has seen that the circulated idea of renewable can give numerous financial advantages to the nation, including its rustic, innate and remote regions.

(2) The interest for the account of provincial sustainable power source in both China and India still faces extreme limitation child the supply side of their money related frameworks, for example, measure of assets, terms and states of assets and accessible financing instruments. In this manner the down to earth pertinence of the numerous money related instruments is somewhat restricted in the business monetary markets of the two nations for RET financing.
Notwithstanding, India has the most unpredictable arrangement of sponsorships and financing courses of action for country sustainable power source ventures contrasted with other Asian countries. China does not yet have a completely created monetary motivator framework for provincial sustainable power source, yet the administration has been offering help for the area since the 1950s. The major monetary motivating forces in presence today incorporate appropriations, charge related impetuses, custom obligations, and evaluating motivators, and the administration is pushing toward increasingly complete amount and cost based help instruments.

(3) India has made extraordinary financing offices to give credits to country sustainable power source ventures at underneath market loan costs. The key organization is IREDA (India Renewable Energy Development Agency), which is the fundamental national supplier of money for RE-ventures. Nearby business banks, thusly, are drawn into RE-financing by the case of IREDA. It as of late expanded its offer funding to $\$ 226$ million, which will enable it to use more elevated amounts of private venture. In contrast to India, Chinese focal government funds rustic sustainable power source through some unique divisions. For instance, it funds innovative work on key sustainable power source advancements through the National Development and Reform Commission (NDRConce in the past the State Development and Planning Commission) and the Ministry of Science and Technology (MOST). Assets offered by MOST amid the tenth Five-Year Plan period will be 3.4 million USD or 28 million CNY. What's more, there are a few endowments for exhibit ventures and instructional classes from the previous SETC, Ministry of Finance (MOF), and Ministry of Agriculture (MOA). The previous SETC's Department of Resource Conservation and Utilization (DORCU) if, low-intrigue credits from the state spending plan to help the improvement of country sustainable power source. The Ministry of Water Resources (MWR) gives low-intrigue advances of around 26 million USD or 300 million CNY for little hydropower improvement.

(4) Both China and India have contrived and tried numerous creative instruments for financing sustainable power source however the inventive methods of the two countries are extraordinary.

\section{CONCLUSION}

In end the examination of financing rustic sustainable power source of China and India unmistakably shows that there are comparable and different choices for financing country sustainable power source among India and China. They are reflected in the earth, channels, instruments and creative components of financing provincial sustainable power source of these two nations, separately. It's clearly that the examination of the likenesses and contrasts among China and India through a correlation of financing rural renewable vitality will be advantageous to advance the experience trade 


\section{International Journal of Engineering Applied Sciences and Technology, 2019 \\ Vol. 4, Issue 5, ISSN No. 2455-2143, Pages 168-174 \\ Published Online September 2019 in IJEAST (http://www.ijeast.com)}

and innovation collaboration in financing rustic sustainable power source of China and India in order to exhaust present day vitality to country territories of two nations. All the more vitally, as two world's driving nations in the advancement of rustic sustainable power source, China's and India's encounters in financing provincial sustainable power source will be of key and handy enthusiasm to other creating part nations and developing centre salary nations in the locale.

\section{REFERENCE}

[1] Bhattacharyya SC. Energy access problem of the poor in India: is rural electrification a remedy? Energy Policy 2006; 34(18):3387-97.

[2] Liming, H. (2009) - Financing rural renewable energy: A comparison between China and India. Renewable and Sustainable Energy Reviews, 13(5), 1096.

[3] Valentine VC. China's Opening to the world: what does it mean for U.S. banks?

[4] Biomass Energy for Rural India (BERI), http://www.undp.org/gef/05/documents/writeups_doc/cc/ BERI_CC_notes15jan.doc.

[5] EREC, European Renewable Energy Export Strategy. http://www.erec-

renewables.org/fileadmin/erec_docs/Documents/Publicati ons/DEF_Export_Strategy.pdf.

[6] Hands On, Series 5: Programme 9 (of 9) - 'A Switch in Time', Plant Power -India, 2005, http://www.handsontv.info/series5/09_ASwitchInTime_re ports/report3.html.

http://www.fdic.gov/bank/analytical/banking/2005nov/arti cle1.html.

[7] Peter Meisen, Overview of renewable energy potential of India,2006http://www.geni.org/globalenergy/library/energ ytrends/currentusage/renewable/Renewable-Energy-

Potential-for-India.pdf. 